ソフトレーザー照射後の線維芽細胞の経時的形態変化

$$
\begin{aligned}
& \text { 高木茂樹土肥宏樹中川敏浩 } \\
& \text { 目井龍一山本茂久 }
\end{aligned}
$$

奥羽大学歯学部口腔解剖学第 2 講座

(主任：山本茂久教授）

（受理：平成 8 年 1 月 5 日）

\title{
Morphological Changes with the Passage of Time of Fibroblasts After Soft Laser Irradiation
}

\author{
Shigeki TAKAGI, Hiroki DOHI, Toshihiro NAKAGAWA, \\ Ryuichi USUI and Shigehisa YAMAMOTO \\ 2nd Department of Oral Anatomy Ohu University, School of Dentistry \\ (Chief: Prof. Shigehisa YAMAMOTO)
}

(Accepted for Publication: January 5, 1996)

\begin{abstract}
To elucidate empirical findings about the accelerated wound healing after soft laser irradiation, we examined how soft laser rays activated mouse normal fidroblasts with varying exposure conditions. Then, we observed interesting morphogical changes in the fibroblasts under the optimal exposure conditions.

We used a gallium-arsenide diode soft laser system with the mean output of $2 \mathrm{~mW}$ emmiting a beam of $904 \mathrm{~nm}$ wavelength. The cells tested were fibroblasts from mice. We evaluated various exposure conditions on the basis of the growth of mitochondria defined by MTT colorimetry 24 hours after exposure. Next, cellular exposure was made with the optimal exposure conditions, and compared cells with and without exposure to the soft rays immediately, 5, 10, 15 and 18 hours after exposure for their morphologic changes.

The optimal condition selected for the mouse fibroblasts was 4-minute A mode irradiation repeated three times. The morphologic examination showed that those fibroblasts were originally spindle-shaped immediately after cell division in both groups. Five hours later the fibroblasts without exposure to the soft ray had changed from the spindle-shaped to polygons, while the exposed ones were spindle-shaped with long cytoplasmic filaments. Ten hours later the not exposed cells had changed to big polygonal bodies, while the exposed cells had changed to the spindle shape with several cytoplasmic filaments. Fifteen hours the not exposed cells remained the same polygonal shapes as before, while the exposed cells almost began to devide. Eighteen hours later the not exposed cells had changed in shape from polygonal to spindle-shaped, while the exposed cells had completed the cell division to be spindle-shaped with long cytoplasmic filaments. In summary, it was clearly demon-
\end{abstract}


strated that the soft laser rays directly act on the fibroblasts to accelerate their cell growth. (J. Jpn. Soc. Laser Dent. $7: 1 \sim 5,1996$ Reprint requests to Dr. Takagi)

\section{Key words=Soft laser : Fibroblasts : Morphological changes}

キーワードニソフトレーザー：線維芽細胞 : 形態変化

\section{緒言}

近年, 各種の医用レーザーの開発が進み, それらの臨 床応用が活発に行われている。とくに歯科領域において, ソフトレーザーが口腔領域の疾患, 抜歯創の治癒あるい

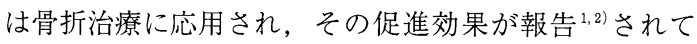
いる。しかしながら, その臨床効果については数多くの 基礎的研究が報告 ${ }^{3-8)}$ されているにも関わらず，未だ一 致した見解を見るに至っていない。

これに対し, 高木 ${ }^{9-11}$ は骨系細胞を用い, ソフトレー ザー照射が細胞に及ぼす影響を検討した結果, ソフトレー ザーは骨系細胞に対し直接作用し, 細胞の機能を促進し ているとすでに報告している。

加えて今回著者らは, 日常経験的に判断されている治 癒促進効果を解明すべく第一歩として, ソフトレーザー 照射が線維芽細胞の活性化にいかに関与しているかにつ いて, 正常マウス線維芽細胞を用い, とくにソフトレー ザーの照射条件を検索し, 併せて至適条件下における細 胞の形態変化を観察したところ興味ある知見が得られた ので報告する。

\section{材料と方法}

\section{1. 使用したソフトレーザー装置}

実験では，SEDATELEC 社製 STOMALASER をソフトレーザー照射装置として使用した。本レーザー は, ガリウム・ヒ素レーザーダイオードを発振源とし, 平均出力 $2 \mathrm{~mW}$, 波長 $904 \mathrm{~nm}$ で, $200 \mathrm{~ns}$ のパルスとし て放射する近赤外線レーザー装置である。また, レーザー をパルス変調させることにより 7 種類のパルスモード $(\mathrm{A} \sim \mathrm{G}: 47.5 \sim 3040 \mathrm{~Hz})$ の出力が可能であり，これら 7 種類のパルスモードはそれぞれ特異な効果があること が報告されている。

\section{2. 培養方法}

実験に用いた細胞は, マウス由来線維芽細胞 Balb/ 3T3 clone A31 (大日本製薬 : 大阪) である。細胞は, Dulbecco's Modification Eagle Medium (DME) (三光純薬 : 東京) に牛胎仔血清 (Costa Mesa, CA : USA）を $10 \%$ 加え,さらに硫酸カナマイシン（明治製 菓 : 東京) を $60 \mu \mathrm{g} / \mathrm{ml}$ の割合で添加した培地で, 温度 $37^{\circ} \mathrm{C}$, 湿度飽和状態, $\mathrm{CO}_{2}$ を $5 \%$ 混和した条件にて培
養し, Dulbecco's phosphate buffered saline （PBS）で作製した $0.003 \%$ actinase E（科研製菓：東 京） $-0.02 \%$ EDTA で分散, 継代した。

\section{3. 細胞の增殖能の測定}

マイクロプレート96well (平型) (Falcon, Becton, Dickinson, Overseas, Inc: USA) を使用し, 非照 射群, 照射群の各 well 内に1000個の細胞を植え込み 培地を加え, 前培養を 24 時間行った。照射は, 2 または 4 分間照射を照射開始から 2 時間間隔で行い, 照射回数 については 1 5 回とし, 周波数はA $(190 \mathrm{~Hz}), \mathrm{C}(760$ $\mathrm{Hz}), \mathrm{E}(3040 \mathrm{~Hz}), \mathrm{F}(47.5 \mathrm{~Hz})$ モードを選択使用し た (照射群)。なお, この際のレーザーのビーム径は, 照射 well 径の70\%程度であり, エネルギー密度は1.03 $\mathrm{J} / \mathrm{cm}^{2}$ である。対照としては, 同様の方法で培養し, 照射しないものを用いた (非照射群)。

増殖能の測定は, 照射 24 時間後にミトコンドリアの増 殖を MTT 比色定量法 (EIA リーダー Model 2550 BIO-RAC）を用い行った。

\section{4. 細胞の形態変化の観察}

$\phi 60 \mathrm{~mm}$ のポリスチレンディッシュ（Falcon, Becton, Dickinson, Cockeysville, MD : USA) 内 に500個の細胞を植え込み培地を加え, 前培養を 24 時間 行った。その後, 分裂直後の細胞を選択, 一方を照射細 胞, 他方を非照射細胞とし, 細胞レベルで照射が可能な レーザー光照射システム ${ }^{12)}$ 使用し, 至適条件下で照射 を行い, 照射直後, $5,10,15,18$ 時間後の非照射細胞 ならびに照射細胞の形態変化について観察した。なお, 照射は細胞核を避け細胞質を標的とした。また,この際 のレーザーのビーム径は, $\phi 1.6 \mu \mathrm{m}$, 標本面でのエネ ルギー量は，レーザー出射口の総エネルギー量の約 $35 \%$ である。

\section{結 果}

\section{1. 照射条件について}

1) 2 分間照射

A， C， E， F モードを前培養後から 2 時間間隔でそ れぞれ 1〜5回照射した結果, 非照射群に比べ照射群に おいて増殖が認められ，照射回数は，各モード群ともに 3 回照射群で増殖を示した。そこで，3回照射群での周 波数においては，A モードは $115 \%$ ，C モードは $103 \%$, 


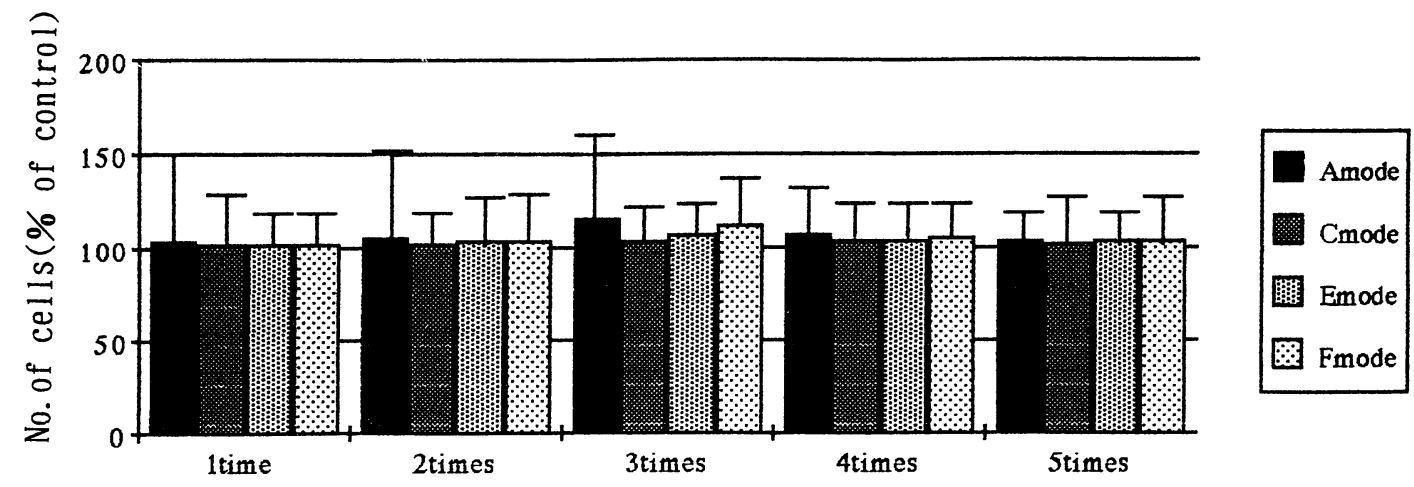

No. of Irradiation times

図 1 Effect of Mode of Two-Minute Laser Irradiation on BALB/3T3 Cells

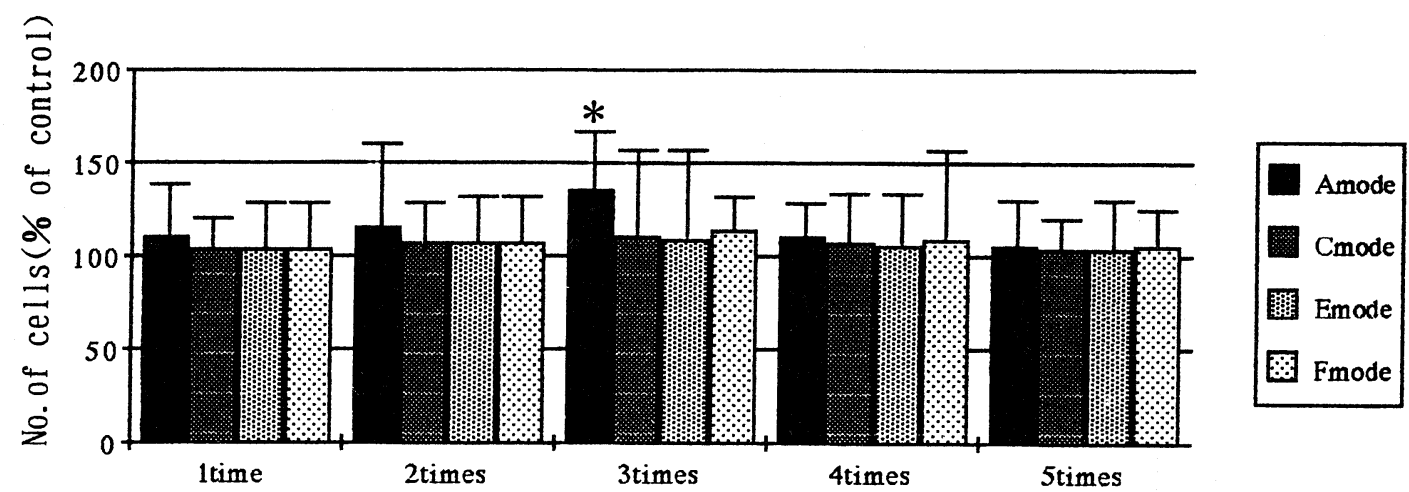

No. of Irradiation times

図 2 Effect of Mode of Four-Minute Laser Irradiation on BALB/3T3 Cells * $\mathrm{P}<0.05$ Compared to control

E モードは $106 \%, F$ モードは111\%とわずかではあるが 他群に比べA モードで増殖は良好であった（図 1)。

2） 4 分間照射

2 分間照射と同様の条件下で実験を行った結果，非照 射群と比較すると照射群において増殖が認められ, 照射 回数は 2 分間照射と同様 3 回照射群で効果的に増殖が認 められた。また，それぞれ 3 回照射群における各モード

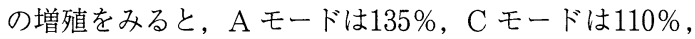
E モードは $108 \% ， F$ モードは113\%と A モードにおい て有意に大きな值を示した（図 2)。

\section{2. 細胞の形態変化について}

標的となる細胞に対しレーザー照射が可能なレーザー 光照射システムを使用し, 分裂直後の細胞を選択, 照射 開始から 2 時間間隔で 4 分間 3 回照射の条件下にて A モードを用い照射した。その結果，分裂直後の細胞はと もに紡錘形を呈していた（図 3)。

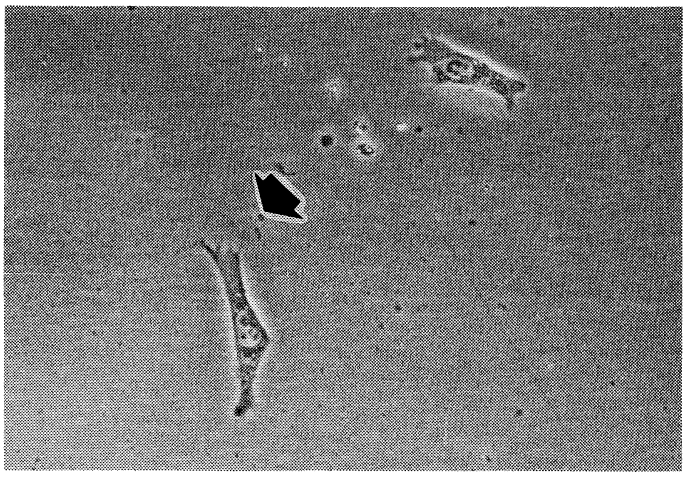

図 3 照射直後 (矢印 : 照射細胞)

照射 5 時間後の非照射細胞の形態は, 紡錘形から多角 形へと変化したのに対し, 照射細胞は長い細胞質突起を 有する紡錘形を呈していた（図 4)。 


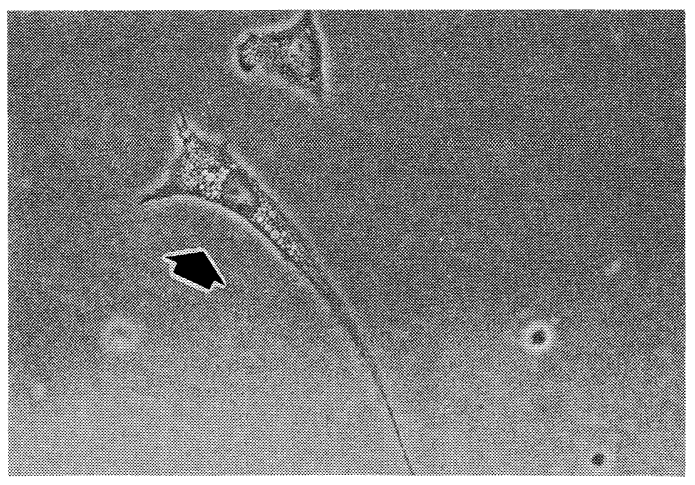

図 4 照射 5 時間後（矢印：照射細胞）

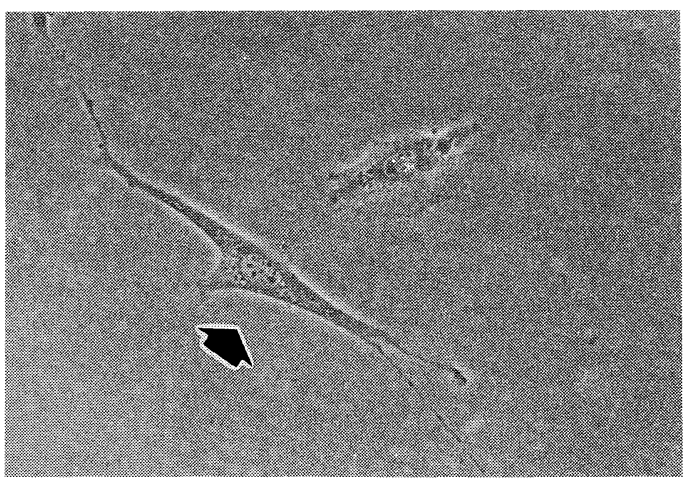

図 5 照射10時間後（矢印：照射細胞）

照射10時間後の非照射細胞は，大きな胞体を有する多 角形へと変化したのに対し, 照射細胞は数本の細胞質突 起を持つ紡錘形へとその形態は変化した（図 5)。

照射15時間後の非照射細胞の形態は, 照射10時間後の 非照射細胞と同様多角形であったのに対し，照射細胞の 形態は分裂直前の様相を呈していた（図 6)。

照射18時間後になると, 非照射細胞は多角形から紡錘 形へとその形態は変化したのに対し, 照射細胞はすでに 分裂を完了し，その形態は長い細胞質突起を有する紡錘 形を呈していた（図 7)。

\section{考察}

歯科領域においてソフトレーザーが盛んに臨床応用さ れ，とくに口腔領域の疾患あるいは抜歯窩に対し著明な 効果があると報告1,2)されている。しかしながら，その 臨床効果についての基礎的研究報告 ${ }^{3-8)}$ も成されている が, ソフトレーザーが細胞の機能を促進するとの報告が ある一方，相反する報告も散見されており，未だ推察の 域を脱していないのが現状である。その理由として，照 射方法, 分析方法, 使用する細胞の植え込み数あるいは レーザーの波長, 周波数, エネルギー密度など, さまざ

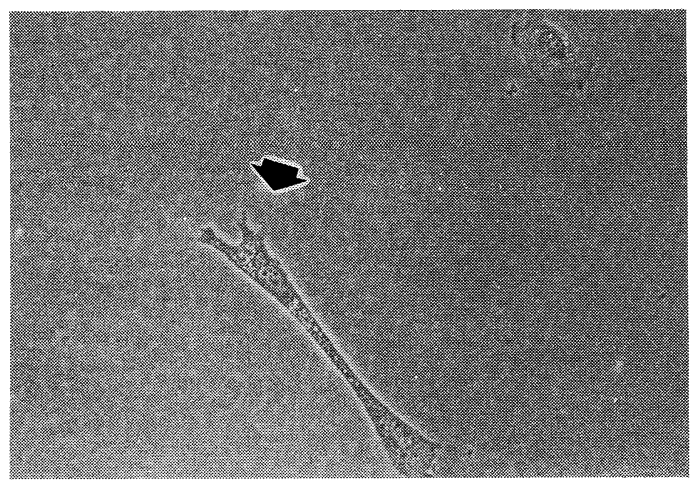

図 6 照射 15 時間後（矢印: 照射細胞）

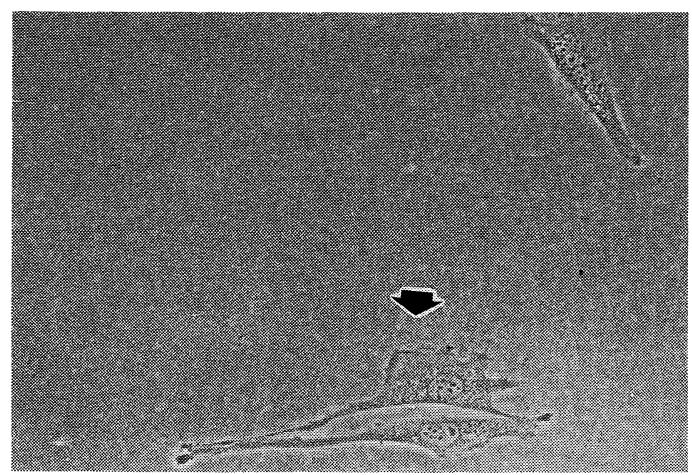

図 7 照射18時間後（矢印：照射細胞）

まな因子の相異が挙げられる。さらに, レーザー光の生 体に打ける吸収率は，レーザーの波長に深く関与するこ とや複雑な生体内機構にあってはレーザーが細胞, 組織 の活性化にいかに関与しているかについては，不明であ る。そこで本研究では, この点に着目し, 組織透過性が 高く,さらに同波長でありながら 7 可変型式の特徵を備 えたストマレーザーを選択し，まず照射条件を検索した。 その結果, 照射回数は, 各モード群ともに 4 分間 3 回照 射で良好な増殖を認めた。また，周波数においては，A モードで有意に大きな值を示した。以上，本細胞に対し 特異的に $\mathrm{A}$ モードで顕著な増殖を示したことは，照射 に際しその周波数の選択が極めて重要であることを示唆 した結果である。

高木 ${ }^{11} は ，$ 骨系細胞を用い，レーザー照射後に Thymidine の誘導体である BrdU を培養液に添加し, 抗体を用い免疫染色を行った。その結果，骨系細胞に対 し，F モード照射群において他群より DNA 合成の促 進が顕著であり, ソフトレーザー照射が細胞に対し直接 的に作用していると報告している。また著者らは，ヒト 表皮角化細胞に抢ける増殖能を測定したところ，特定の 周波数で良好な増殖を認めた結果をすでに得ている。こ 
れらのことを考え合わせると, 各種培養細胞に対するソ フトレーザー照射の効果を左右あるいは助長する因子は その周波数の違いが決定的であることは明らかである。

そこで, 至適条件下における細胞の形態変化では, 照 射18時間後の非照射細胞は, 胞体がやや大きくなるもの の分裂の様相は認められなかった。一方，A モード照 射細胞はすでにこの時期に分裂を完了していた。このよ うに, 形態学的にも A モードで分裂を早期に認めたこ とは,ソフトレーザーは細胞に対し, 直接的に作用し, 細胞の機能とくに増殖能を促進していることが判明した。 いずれにせよ，今回の結果はこれまで経験的に判断さ れていた照射条件を細胞レベルで証明し，加えて，均一 な細胞群からなる実験系において, 同波長のソフトレー ザーで照射回数や周波数の違いにより細胞の増殖能に大 きな違いがみられたことは，極めて興味深い事実である。

\section{結論}

著者らは, 日常経験的に判断されている治癒促進効果 を解明すべく第一歩として, ソフトレーザー照射が線維 芽細胞の活性化にいかに関与しているかについて, 正常 マウス線維芽細胞を用い, とくにソフトレーザーの照射 条件の立場から検索し, 併せて至適条件下における細胞 の形態変化を観察した結果，以下の結果を得た。

1. 本細胞に対し, 照射回数は 4 分間 3 回照射におい て効果的な増殖を示した。

2. 本細胞に対し, 各周波数群において A モードで 顕著な増殖を示した。

3. 至適条件下における照射18時間後の照射細胞は, すでに分裂を完了し，その形態は長い細胞質突起を有す る紡錘形を呈していた。

以上の結果から，ソフトレーザーは細胞に対し直接的 に作用し, 至適条件下において細胞の増殖能を促進して いることが明らかとなった。

\section{文献}

1）神川喜代男, 大西俊輝, 鈴木正根, 金谷元徳, 柴本 博 : 痛みに対するレーザー治療．日本レーザー医学会誌，3： 345-348, 1982.

2）清水良一 : 低出力レーザー照射による口腔顔面部の炎症性 病変の治療効果. 日歯評, $502: 236-242,1984$.

3）長沢明範, 浅井 浩, 山本 肇, 加藤一一：レーザーの骨 組織修復促進効果に関する試験的研究. 日本レーザー医学 会誌, $7: 73-74,1987$.

4) Trelles, M. A. and Mayayo, E.: Bone Fracture Consolidates Faster With Low-Power Laser. Lasers in Surgery and Medicine, $7: 36-45,1987$.

5) Ohta, A., Abergel, R. P. and Utitto, J.: Laser Modulation of Human Immune System: Inhibition of Lymphocyte Proliferation by a Gallium-Arsenide Laser at Low Energy. Lasers in Surgery and Medicine, 7:199 $-201,1987$.

6）新谷博明, 落合 力, 永井哲夫, 野本種邦 : 低出カレーザー の基礎的研究II. 細胞 DNA 合成に及ぼす影響について。 日本レーザー医学会誌, $7: 95-96,1987$.

7）山田邦雄, 松井宣夫, 蟹江良一, 大塚隆信, 服部正広, 加 藤泰治 : 低出力レーザーの関節組織（軟骨，骨，滑膜）に 及ぼす生体作用。日本レーザー医学会誌, $10 ： 93-96,1989$.

8）山田邦雄, 松井宣夫, 大塚隆信, 服部正広, 加藤泰治 : 低 出力レーザー照射が RA 滑膜培養細胞の DNA 合成能に 及ぼす影響について。 日本レーザー医学会誌, $10: 3-10$, 1990.

9）高木茂樹, 中川敏浩, 藤山正之, 山本茂久 : ソフトレーザー の効果に関する基礎的研究. 日本レーザー医学会誌, 13 : 21-26, 1992.

10）高木茂樹, 中川敏浩, 山本茂久：ソフトレーザー照射後の 培養細胞の経時的形態変化. 口腔組織培養研究会誌, $3: 1$ 6, 1994.

11）高木茂樹：骨系細胞に対するソフトレーザーの効果.（印刷 中)

12）高木茂樹, 中川敏浩, 藤山正之, 山本茂久：培養細胞用半 導体レーザー照射システムの試作. 日本レーザー医学会誌, 13 : 17-20, 1992. 